\title{
Why high cholesterol levels help hematological malignancies: role of nuclear lipid microdomains
}

\author{
Michela Codini ${ }^{1 \dagger}$, Samuela Cataldi ${ }^{1 \dagger}$, Andrea Lazzarini ${ }^{2}$, Anna Tasegian ${ }^{1}$, Maria Rachele Ceccarini ${ }^{1}$, \\ Alessandro Floridi ${ }^{2}$, Remo Lazzarini ${ }^{2}$, Francesco Saverio Ambesi-Impiombato ${ }^{3}$, Francesco Curcio ${ }^{3}$, \\ Tommaso Beccari ${ }^{1}$ and Elisabetta Albi $^{* *}$
}

\begin{abstract}
Background: Diet and obesity are recognized in the scientific literature as important risk factors for cancer development and progression. Hypercholesterolemia facilitates lymphoma lymphoblastic cell growth and in time turns in hypocholesterolemia that is a sign of tumour progression. The present study examined how and where the cholesterol acts in cancer cells when you reproduce in vitro an in vivo hypercholesterolemia condition.

Methods: We used non-Hodgkin's T cell human lymphoblastic lymphoma (SUP-T1 cell line) and we studied cell morphology, aggressiveness, gene expression for antioxidant proteins, polynucleotide kinase/phosphatase and actin, cholesterol and sphingomyelin content and finally sphingomyelinase activity in whole cells, nuclei and nuclear lipid microdomains.

Results: We found that cholesterol changes cancer cell morphology with the appearance of protrusions together to the down expression of $\beta$-actin gene and reduction of $\beta$-actin protein. The lipid influences SUP-T1 cell aggressiveness since stimulates DNA and RNA synthesis for cell proliferation and increases raf1 and E-cadherin, molecules involved in invasion and migration of cancer cells. Cholesterol does not change GRX2 expression but it overexpresses SOD1, SOD2, CCS, PRDX1, GSR, GSS, CAT and PNKP. We suggest that cholesterol reaches the nucleus and increases the nuclear lipid microdomains known to act as platform for chromatin anchoring and gene expression.
\end{abstract}

Conclusion: The results imply that, in hypercholesterolemia conditions, cholesterol reaches the nuclear lipid microdomains where activates gene expression coding for antioxidant proteins. We propose the cholesterolemia as useful parameter to monitor in patients with cancer.

Keywords: $\beta$-actin, Hypercholesterolemia, Lymphoma cells, Sphingomyelin, Sphingomyelinase

\section{Background}

Cholesterol (CHO)-rich diet is now considered an important risk factor for cancer development [1-3]. However, although detrimental effect of high level of $\mathrm{CHO}$ for cancer progression have been increasingly noted, we do not know the mechanisms involved. Llaverias et al. [4] reported that hypercholesterolemia (hyperCHO), in association with oncogenic stimuli, leaded to accelerated tumour formation with subsequent hypocholesterolemia

\footnotetext{
*Correspondence: elisabetta.albi@gmail.com

${ }^{\dagger}$ Equal contributors

'Department of Pharmaceutical Sciences, University of Perugia, Perugia, Italy Full list of author information is available at the end of the article
}

(hypoCHO). Already Iso et al. [5] had previously shown that patients with liver cancer often exhibited hypoCHO, which seemed to be a symptom rather than a cause of cancer. We demonstrated that severe hypoCHO was a sign of cancer progression in patients with acute lymphoid leukemia [6]. In vitro, when serum $\mathrm{CHO}$ concentration was $800 \mathrm{nM}$ corresponding to $280 \mathrm{mg} / \mathrm{dl}$ in the blood of patients, non-Hodgkin's $\mathrm{T}$ cell human lymphoblastic lymphoma cells (SUP-T1) incorporated $\mathrm{CHO}$ with avidity and used it for their proliferation [6]. Therefore normal $\mathrm{CHO}$ concentration did not influence tumour growth; otherwise hyperCHO facilitated the entry of $\mathrm{CHO}$ into the cells by stimulating cell growth and 
inducing severe hypoCHO [6]. Recently it has been highlighted that cell membrane specific lipid microdomains (LMs) rich in $\mathrm{CHO}$ and sphingomyelin (SM) or lipid rafts controlled cancer cell signalling [7, 8]. Cancer progression involved dysregulation of lipid rafts [9]. Increased $\mathrm{CHO}$ content in lipid rafts is associated with greater survival of prostate cancer cells [10]. After cell treatment with $\mathrm{CHO}$ disrupting or usurping agents, raftassociated proteins and lipids were dissociated and disease severity was mitigated [11].

We previously demonstrated the presence of LMs in the nucleus, in association with inner nuclear membrane (Nuclear Lipid Microdomains, NLMs), where they acted as platform for active chromatin anchoring, DNA duplication and transcription process [12, 13]. CHO-SM relationship in NLM was different in normal and cancer cells [14]. Dexamethasone localized in NLM where it acted as inhibitor of SUP-T1 cell growth [15].

Plasma membrane was supported by an actin network. The dynamic regulation of actin polymerization into filaments and depolymerization into monomers was the key for its many functions during cell motility, intracellular transport and cell shape maintenance [16]. Regulation of the actin cytoskeleton was imperative to normal cell function. Tumour invasion and metastasis were increasingly being associated with deregulation of the actin system [17]. In the diffuse large B-cell lymphoma a $\beta$ actin mutation was identified [18].

Despite the anticancer role of antioxidant enzymes has been widely demonstrated, proliferation, invasiveness, migration, apoptosis and drug resistance of cancer have been associated with the over-expression of antioxidant enzymes [19]. Superoxide dismutases (SODs) are a family of enzymes responsible for the detoxification of ROS; copper-zinc SOD1 is the predominant dismutase in the cytoplasm whereas manganese SOD2 is located in the mitocondria and SOD3 is extracellular [20]. The association with the copper chaperone for SOD (CCS) delivers $\mathrm{Cu}$ to SOD1, forms disulfide bond and induces activation of copper/zinc SOD1 [21]. Glutathione (GSH) is one of the main antioxidants. The oxidized form of GSH (GSSG) is reduced back to GSH by the NADPHdependent catalysis of the flavoenzyme GSH reductase (GSR); the novo GSH biosynthesis requires glutathione synthase (GSS) enzyme [22]. Peroxiredoxins (PRDXs) are a family of non-selenium-dependent glutathione peroxidases which destroy peroxides, organic hydroperoxides and peroxynitrite [23]. Glutaredoxins (GRX), also known as thioltransferases, are a family of glutathionedependent thiol oxidoreductase enzymes important in the maintenance of thiol redox state; they catalyze the removal of GSH from proteins with a disulfide bridge; GRX2 is an isoform presents in mitochondria and nuclei [24]. Catalase (CAT) is primarily an intracellular enzyme that induces the decomposition of hydrogen peroxide to water and oxygen. Polynucleotide kinase/phosphatase (PNKP) is an enzyme involved in the repair of DNA strand breaks, including base excision repair, single and double-strand break repair. It possesses 3'-DNA phosphatase and $5^{\prime}$-DNA kinase activities useful to restore the strand structure and consequently to permit the action of DNA polymerases and ligases [25].

We aimed to test the hypothesis that hyperCHO might have an important role in the regulation of NLM by influencing consequently the transcription of genes for antioxidant proteins useful for the vitality, growth and aggressiveness of lymphoblastic lymphoma cells.

\section{Results}

\section{How the high level of cholesterol influences} lymphoblastic lymphoma cells

We have previously demonstrated that by enriching the culture medium with $800 \mathrm{nM} \mathrm{CHO}$ you reached a level of $\mathrm{CHO}$ corresponding to hyperCHO $(280 \mathrm{mg} / \mathrm{dl}$ in the blood of patients). Therefore we used $800 \mathrm{nM} \mathrm{CHO}$ to test the effect of hyperCHO on SUP-T1 cells.

First we investigated the possible changes of cell morphology (Fig. 1). Hematoxylin-eosin staining of control cells showed round cells with very big nuclei intensely colored occupying almost the whole cell, as previously shown [26]. No significant differences were in the major and minor axis $(4.37 \mu \mathrm{m} \pm 0.25)$; cell surface area was $19.96 \pm 1.75 \mu \mathrm{m}^{2}$. Experimental cells changed the shape, the major axis was $5.25 \mu \mathrm{m} \pm 1.07$ and the minor axis was $3.91 \mu \mathrm{m} \pm 1.10$; however cell surface area was similar to that of control sample $\left(21.33 \pm 1.30 \mu \mathrm{m}^{2}\right)$. Cellular protrusions were evident (Fig. 1). The expression fold of $\beta$-actin gene expression in Ex sample respect to $C$ sample was $0.7888 \pm 0.056$, by indicating a gene down-regulation. The immunoblotting analysis of $\beta$ actin showed the presence of the band protein in C cells corresponding to $43 \mathrm{kDa}$ apparent molecular weight (Fig. 2a); in Ex cells the band was reduced 2.62 times (Fig. 2b). To investigate if the high $\mathrm{CHO}$ levels can increase cancer cell malignancy, such as proliferation, migration and/or invasion, we analyzed first DNA and RNA synthesis after $48 \mathrm{~h}$ of cell culture. The results showed that $800 \mathrm{nM}$ CHO stimulated 1.68 times DNA synthesis and 1.63 times RNA synthesis (Fig. 3), by indicating that $\mathrm{CHO}$ influenced cell proliferation and activity. Then, we analyzed the behavior of raf1 and ecadherin, as molecules involved in migration and/or invasion of cancer cell $[27,28]$. The Fig. 4a showed that the band corresponding to $69 \mathrm{kDa}$ apparent molecular weight, highlighted by anti-raf antibody, was increased after $\mathrm{CHO}$ treatment. The band area density analysis demonstrated that the value of raf1 was higher 1.59 times in Ex sample (Fig. 4b). High levels of $\mathrm{CHO}$ 


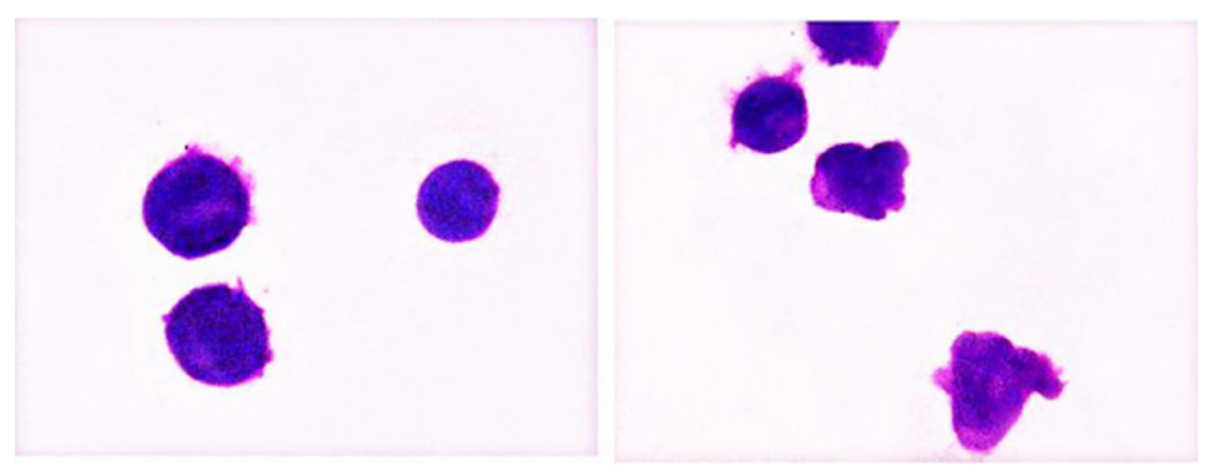

Control

Experimental

Fig. 1 SUP-T1 morfology. The cells were cultured without (control) or with 800nM CHO (experimental) for three days, then they were treated as reported in Materials and Methods section

stimulated strongly e-cadherin (Fig. 4a) whose value increased 5.26 times as shown in Fig. 5, where the gene expression is referred to that of $\mathrm{C}$ cells. $\mathrm{CHO}$ treatment did not change GRX2 expression, overexpressed PRDX1 1.3 times, SOD1 and SOD2 about 1.5 times, GSR-GSSCAT between 2.0 and 2.52 times, CCS 3.06 times and PNKP 3.75 times.

\section{HyperCHO influences nuclear lipid microdomains}

Since we previously demonstrated the role of the SUPT1 NLM in transcription process [15], we tested the possibility that the culture medium hyperCHO could influence NLM composition and function. The level of $\mathrm{N}$ and NLM purification was similar to that previously

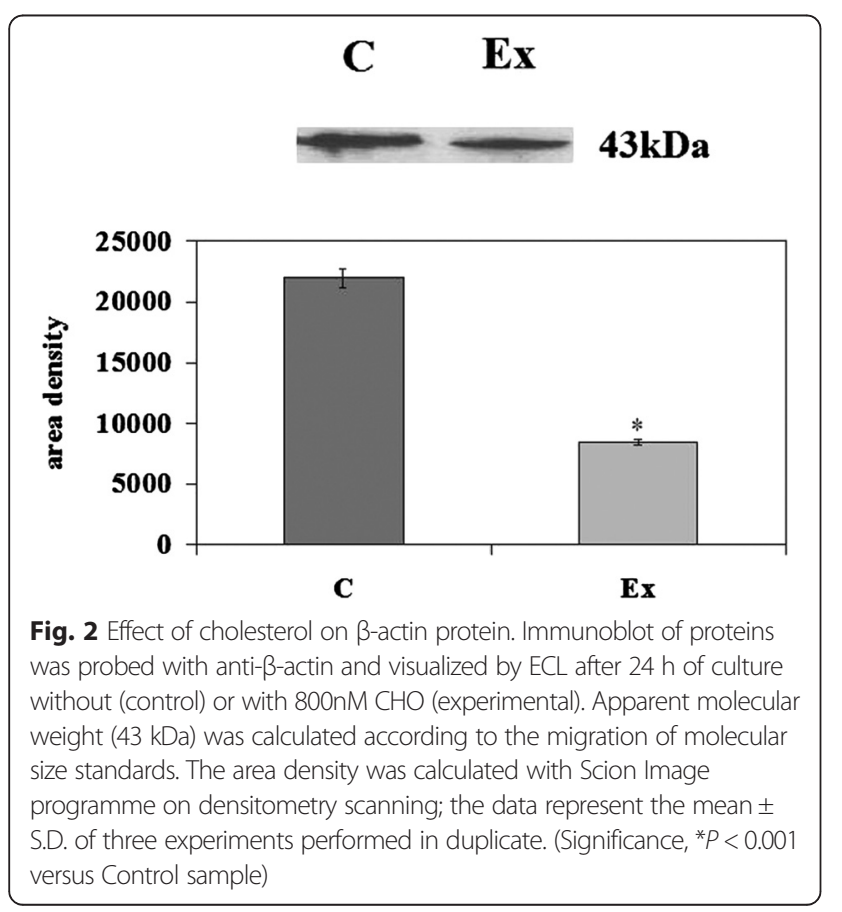

reported $[12,15,29]$. In the Ex cells. the levels of protein and DNA expressed as $\mu \mathrm{g} / 10^{6}$ cells did not change in cell, N and NLM in comparison with $\mathrm{C}$ samples; the level of RNA increased 1.31 times only in NLM. The level of $\mathrm{CHO}$ increased 1.59, 1.52, 1.78 in cell, $\mathrm{N}$ and NLM, respectively; the level of SM increased 1.94, 1.37, 1.90 in cell, N and NLM, respectively (Fig. 6a). If you express the data of NLM as $\mu \mathrm{g} / \mathrm{mg}$ protein you can see that only $\mathrm{CHO}$ and SM changed (Fig. 6b). The SMase activity was inhibited 1.94 times in cells, 1.37 times in N and 1.90 times in NLM. (Fig. 7). By expressing the data as percentage of activity respect to the control samples, it was evident that the activity in cells and in NLM was more inhibited than in $\mathrm{N}$ (Fig. 7).

\section{Discussion}

The main finding of this study is that by reproducing in vitro a condition of in vivo hyperCHO, lymphoma lymphoblastic cells overexpressed genes for antioxidant proteins (SOD1, SOD2, CCS, GSR, GSS and CAT) with the only exception of GRX2. These proteins counteract the oxidative stress that induces damage of lipids, nucleic acids and proteins, by altering their functions. It has been demonstrated that SOD2 polymorphism was associated with prostate cancer risk [30]. The sequestration of GSR by tumour cells yielded them less susceptible to oxidative stress, conferring a selective growth advantage in tumour cells [31]. The overexpression of GSS was in human colorectal cancer cell lines and tissues compared with normal samples [32]. PRDX1 was identified as a tumor-associated antigen in esophageal squamous cell carcinoma [33] and acted via mTOR/ p70S6K pathway [34]; its overexpression was demonstrated in multiple myeloma [35], was associated with tumour angiogenesis and progression in human hepatocellular cancer [36], provided resistance to docetaxel treatment of lung cancer [37] and to alkylating agent 


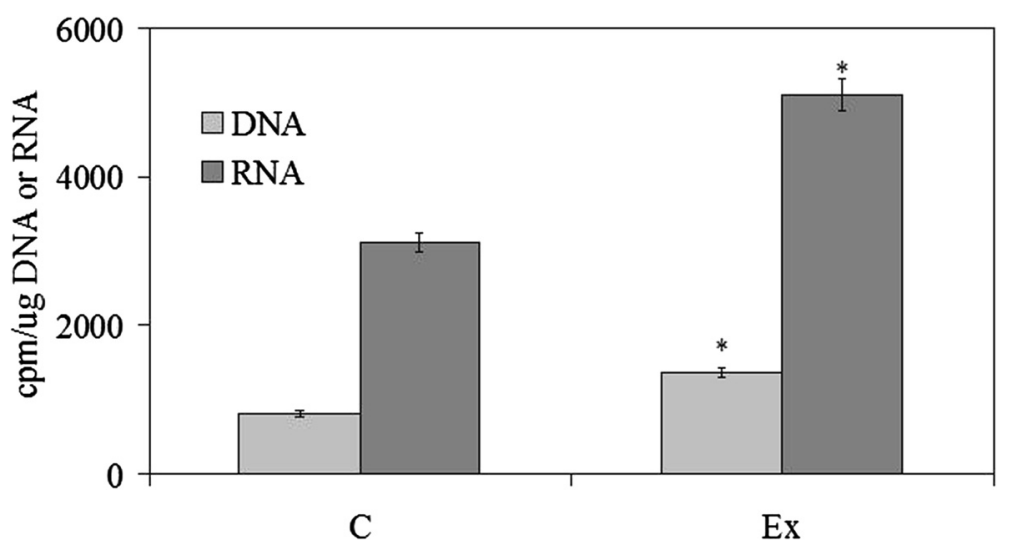

Fig. 3 Effect of cholesterol on DNA and RNA synthesis. DNA synthesis was studied by evaluating the incorporation of ${ }^{3} \mathrm{H}$-thymidine in the DNA and RNA synthesis by evaluating the incorporation of ${ }^{3} \mathrm{H}-\mathrm{UTP}$ in the RNA. The specific activity was calculated as cpm/ $\mu \mathrm{g}$ DNA and cpm/ $\mu \mathrm{g}$ RNA, respectively. The data represent the mean \pm S.D. of three experiments performed in duplicate. (Significance, ${ }^{*} P<0.001$ versus Control sample)

bis-chloroethyl nitroso urea of oligodendroglial tumors [38]. Increased CAT levels were found in patients with non-small cell lung cancer compared to controls $[39,40]$.

We also showed that PNKP, as enzyme involved in the repair of DNA strand breaks was overexpressed after $\mathrm{CHO}$ incubation, by indicating that the cells were protected from the damage. On the other hand it was demonstrated that small inhibitors of PNKP

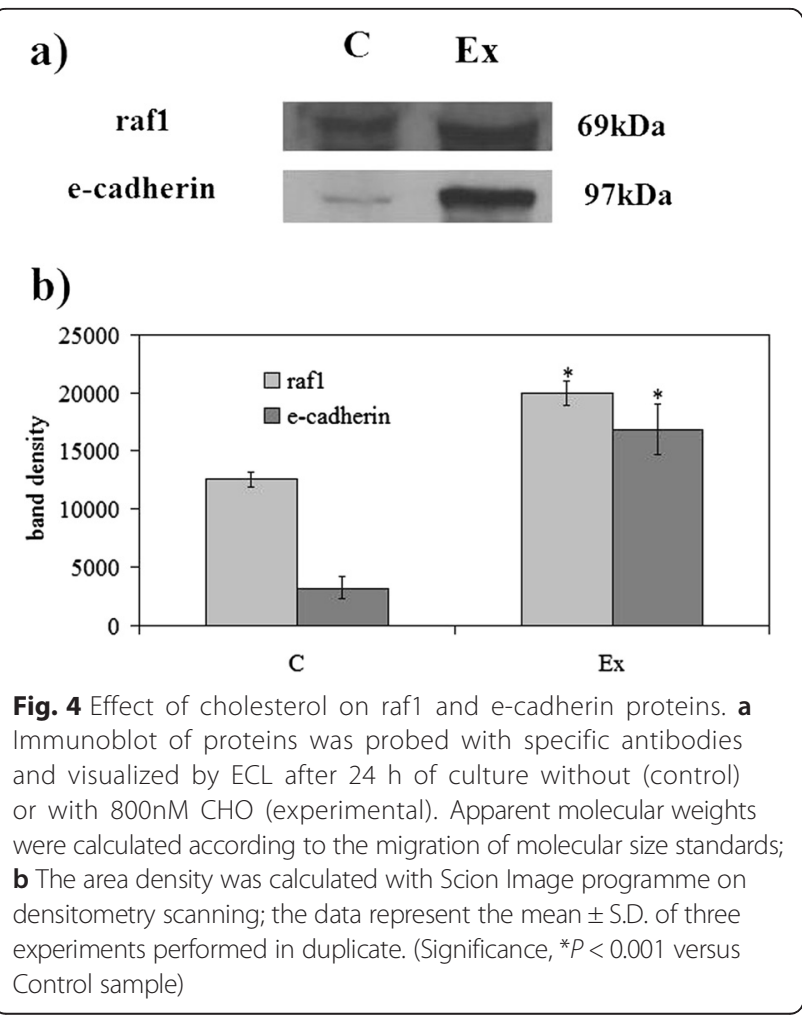

increased the response to radiations of human lung carcinoma cells [41].

Therefore we reported the first observation in literature showing the $\mathrm{CHO}$-antioxidant proteins- PNKP relationship in cancer. The results obtained might explain why the hyperCHO stimulated key proteins involved in cell cycle and survival (RNA polymerase II, STAT3, PKCzeta, PPARgamma and Cyclin D) and decreased Bax protein in SUP-T1 cells [6]. Here we showed that hyperCHO induced changes in cell shape with the appearance of protrusions that were notably associated with invasiveness and metastasis [40]. It was shown that tumour cell migration and invasion required actin cytoskeletal reorganization [42]; in addition, $\beta$-actin mutation was found in B-cell lymphoma [18]. Our results highlighted that the $\beta$-actin gene was downregulated and $\beta$-actin protein was reduced. The possibility that the $\beta$ actin was mutated also in our experimental model and therefore it was underestimated should be considered. In any case a change of $\beta$-actin might be responsible for the morphological modification of the cells. We have shown a correlation between hyperCHO and increase of DNA and RNA synthesis as well as raf1 and e-cadherin content, important molecules for cancer progression [27, 28]. The results obtained up to this point induced us to investigate about the possible mechanism of action of $\mathrm{CHO}$ in the regulation of gene expression. We previously demonstrated that $\mathrm{CHO}$ present in inner nuclear membrane linked SM to form NLM that acted as platform for active chromatin anchoring and gene expression $[12,13,15]$. So we wondered if the $\mathrm{CHO}$, incorporated into the cells, might reach NLM by influencing their composition and, as a result, their function. Thus we demonstrated that hyperCHO is responsible for the enrichment of $\mathrm{CHO}$ in NLM and for the inhibition of SMase activity. In intranuclear environment existed two $\mathrm{CHO}-\mathrm{SM}$ pools 


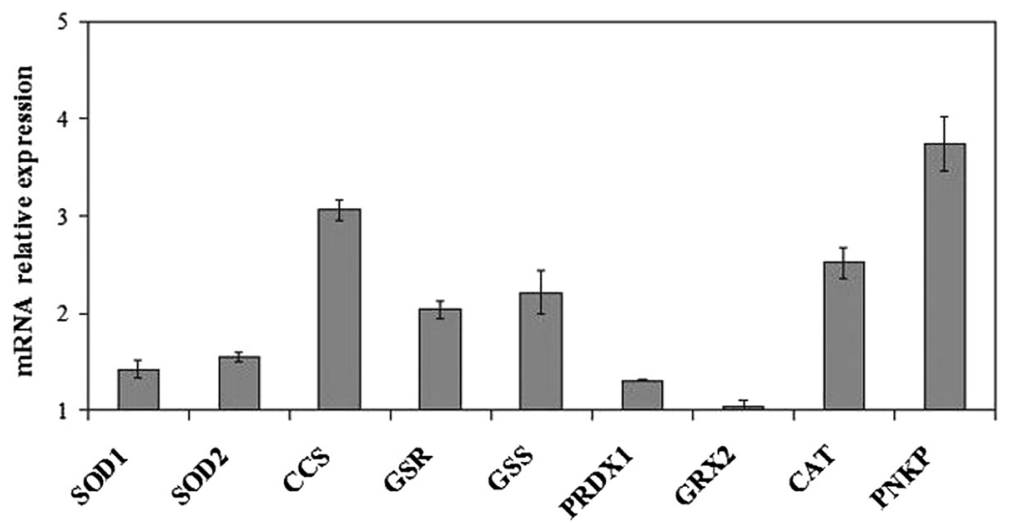

Fig. 5 Effect of cholesterol on SOD1, SOD2, CCS, GSR, GSS, PRDX1, GRX2, CAT, PNKP expression. RTqPCR analysis was performed in control (without $\mathrm{CHO}$ ) and experimental SUP-T1 cells (with 800nM CHO) collected after $24 \mathrm{~h}$ of culture. The results were normalized with the levels of the GAPDH and expressed as mRNA of experimental sample versus control sample. Data are expressed as the mean \pm S.D. of 3 independent experiments performed in three PCR replicates

regulated by SMase, $\mathrm{CHO}-\mathrm{SM}$ linked pool and $\mathrm{CHO}-$ SM free pool $[43,44]$. The intranuclear CHO-SM linked pool was that present in NLM [12]. CHO, in turn, was able to regulate SMase [43, 44]. Thus it was possible to hypothesise that $\mathrm{CHO}$ inhibited SMase to have more SM to link and to enrich the nucleus of platforms for gene expression.

\section{Conclusion}

In conclusion our data showed an association between hyperCHO and enrichment of NLM in inner nuclear membrane, increase of DNA and RNA synthesis and changes of antioxidant gene expression. It is possible to suggest that $\mathrm{CHO}$, by keeping under control the oxidative status of cancer cells, might allow their vitality and growth.

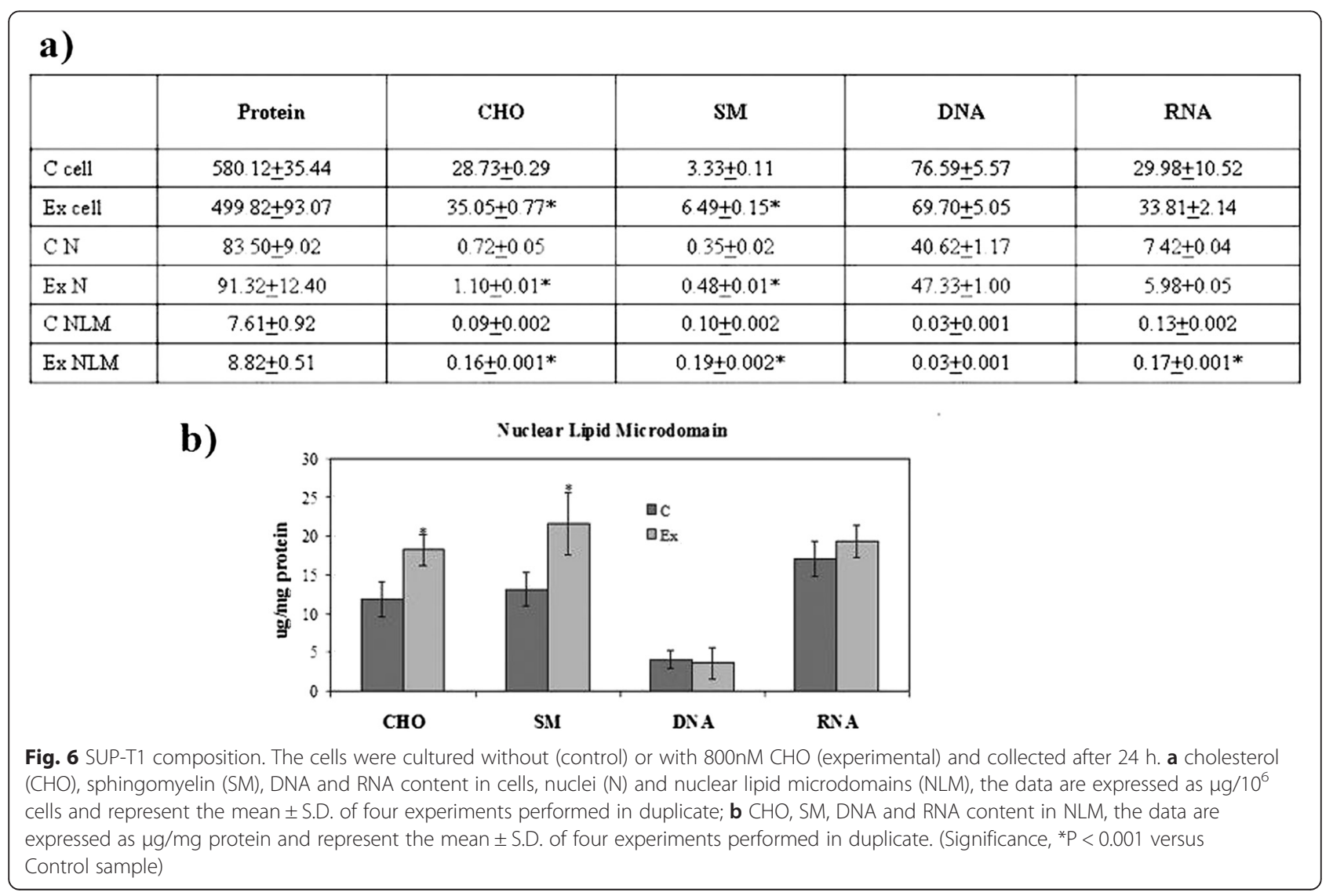




\begin{tabular}{|l|c|}
\hline & Sphingomyelinase \\
\hline C cell & $2980.03+146.88$ \\
\hline Ex cell & $1650.72 \pm 222.10^{*}$ \\
\hline C N & $820.56 \pm 11.38$ \\
\hline Ex N & $644.94 \pm 20.20^{*}$ \\
\hline C NLM & $180.33 \pm 9.42$ \\
\hline Ex NLM & $103.07 \pm 12.60^{*}$ \\
\hline
\end{tabular}

b)

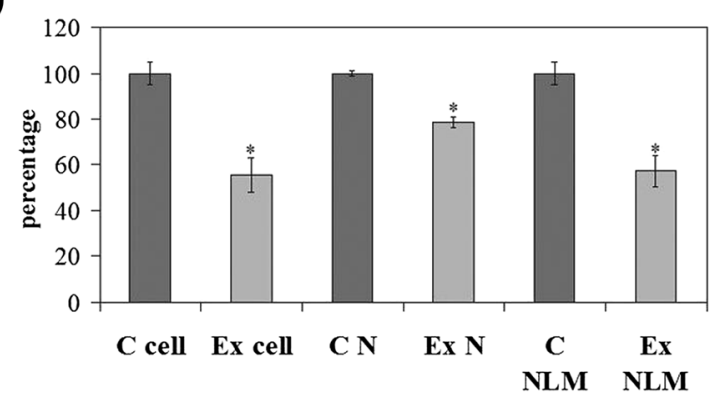

Fig. 7 Sphingomyelinase activity. The cells were cultured without (control) or with 800nM CHO (experimental) and collected after 24 h; cell, nuclei (N) and nuclear lipid microdomains (NLM) were prepared as reported in Materials and Methods section. a The data are expressed as pmol/mg protein/min; $\mathbf{b}$ the data are expressed as percentage respect to control samples. (Significance, ${ }^{*} P<0.001$ versus Control sample)

\section{Methods}

\section{Materials}

Non-Hodgkin's T cell human lymphoblastic lymphoma (SUP-T1) were obtained from Biological Materials Bank (ICLC)-CBA-Genoa. ${ }^{3} \mathrm{H}$ palmytic acid, $\left[{ }^{3} \mathrm{H}\right]$ thymidine and $\left[{ }^{3} \mathrm{H}\right]$ UTP $(41 \mathrm{Ci} / \mathrm{mmol}, 1.52 \mathrm{TBq} / \mathrm{mmol})$ were obtained from Amersham Pharmacia Biotech (Rainham, Essex, UK); Ecoscint A was obtained from National Diagnostic (Atlanta, GA, USA); Thin layer chromatography (TLC) plates (silica Gel G60) were from Merck, Darmstadt, Germany; CHO, SM, Fetal bovine serum (FBS), RPMI 1640 Medium, PSF (penicillin, streptomycin and fungizone) were purchased from Sigma Aldrich Co. (St. Louis, MO, USA). Anti-actin, antiRaf1, anti-phosphoRaf1 and anti-E-cadherin antibodies were obtained from Santa Cruz Biotechnology, Inc. (California, USA).

\section{Cell culture and treatments}

SUP-T1 cells were grown as previously reported [6]. For each experiments, two lots of cells were prepared: the control sample $(\mathrm{C})$ without $\mathrm{CHO}$ and the experimental sample (Ex) with 800nM CHO. After $24 \mathrm{~h}$ of culture, part of the cells were used for their analysis and part for
Nuclei (N) and Nuclear Membrane Microdomains (NLM) purification.

\section{Cell morphology}

SUP-T1 cells, cultured for three days, were fixed and submitted to the hematoxylin-eosin staining as previously reported [26] and analyzed by inverted microscopy EUROMEX FE 2935 (ED Amhem, The Netherland) equipped with a CMEX 5000 camera system (40x magnification). The analysis of cell size was performed by ImageFocus software.

\section{DNA and RNA synthesis}

The DNA and RNA synthesis was studied in synchronized cells by using $\left[{ }^{3} \mathrm{H}\right]$-thymidine or $\left[{ }^{3} \mathrm{H}\right]$-UTP as precursor, previously reported $[44,45]$. After syncronization, the cells were cultured for $48 \mathrm{~h}$ of in the absence $(\mathrm{C})$ or presence $(\mathrm{Ex})$ of $800 \mathrm{nM} \mathrm{CHO} ; 1 \mu \mathrm{Ci}\left[{ }^{3} \mathrm{H}\right]$-thymidine or $1 \mu \mathrm{Ci}\left[{ }^{3} \mathrm{H}\right]$-UTP was added to the culture medium $3 \mathrm{~h}$ before the analysis. The data of the radioactivity were referred to the DNA or RNA amount and expressed as $\mathrm{cpm} / \mu \mathrm{g}$ DNA and cpm/ $\mu \mathrm{g}$ RNA, respectively.

\section{Nuclei purification}

The nuclei $(\mathrm{N})$ were purified from $20 \times 10^{6}$ SUP-T1 cells and checked for possible cytoplasmic contamination as previously reported [43].

\section{Nuclear Lipid Microdoman purification}

The Nuclear Lipid Microdomains (NLMs) were purified from $1 \times 10^{9}$ SUP-T1 cells and checked for possible and nuclear contamination as previously reported [15].

\section{Biochemical determinations}

Protein, DNA and RNA contents were determined as previously reported [43].

\section{Western blotting}

About $30 \mu \mathrm{g}$ of cell proteins were submitted to SDSPAGE electrophoresis in $10 \%$ polyacrylamide slab gel. Proteins were transferred into nitrocellulose for $90 \mathrm{~min}$ as previously described [12]. The membranes were blocked for $30 \mathrm{~min}$ with $0.5 \%$ no-fat dry milk in PBS $(\mathrm{pH} 7.5)$ and incubated overnight at $4{ }^{\circ} \mathrm{C}$ with the $\beta$ actin specific antibody. The blots were treated with HRP-conjugated secondary antibodies for $90 \mathrm{~min}$. Visualization was performed with the enhanced chemiluminescence kit from Amersham (Rainham, Essex, UK). The apparent molecular weight of $\beta$-actin, raf1 and ecadherin was calculated according to the migration of molecular size standards. The area density of the bands was evaluated by densitometry scanning and analyzed with Scion Image. 


\section{Lipid analysis}

Lipids were extracted and $\mathrm{CHO}$ measured, after thinlayer chromatography (TLC) separation, as previously reported [46]. To evaluate SM the cells were incubated with $1 \mu \mathrm{Ci} / \mathrm{ml}$ of ${ }^{3}[\mathrm{H}]$ palmitic acid, diluted with cold palmitic acid as previously reported [15]. After $24 \mathrm{~h}$, the cells from 5 flasks were pooled and NLM were purified. The lipids were extracted, separated on TLC and analysed as reported by Cascianelli et al. [6]. The radioactivity was measures in counting vials with $10 \mathrm{ml}$ Ecoscint $\mathrm{A}$ and $1 \mathrm{ml}$ water and the radioactivity was measured with a Packard liquid scintillation analyser (Packard Instrument Company, Meriden, CT, USA).

\section{Sphingomyelinase activity}

The sphingomyelinase (SMase) activity was detected according to Albi et al. [47]. Incubations were performed at $37{ }^{\circ} \mathrm{C}$ for $45 \mathrm{~min}$. The reaction was stopped by adding $2 \mathrm{ml}$ chloroform and methanol (2:1), $0.4 \mathrm{ml}$ of $0.5 \%$ $\mathrm{NaCl}$ was added to the tubes and vortexed. After centrifugation at $2000 \mathrm{RPM} \times 10 \mathrm{~min}$, the upper phase was removed and $0.5 \mathrm{ml}$ was diluted in counting vials with $10 \mathrm{ml}$ Ecoscint $\mathrm{A}$ and $1 \mathrm{ml}$ distilled water; radioactivity was measured with a Packard liquid scintillation analyzer.

\section{Reverse transcription quantitative PCR (RTqPCR)}

Control and experimental SUP-T1 cells were used for total RNA extraction performed by using RNAqueous -4PCR kit (Ambion Inc., Austin, Texas), as previously reported [25]. cDNA was synthesized under the following conditions: $50{ }^{\circ} \mathrm{C}$ for $2 \mathrm{~min}, 95{ }^{\circ} \mathrm{C}$ for $10 \mathrm{~min}, 95{ }^{\circ} \mathrm{C}$ for $15 \mathrm{~s}$ and $60^{\circ} \mathrm{C}$ for $1 \mathrm{~min}$ for 40 cycles. RTqPCR was performed using Master Mix $\operatorname{TaqMan}^{\circ}$ Gene Expression and 7.300 RT-PCR instrument (Applied Biosystems), targeting $\beta$-actin (ACTB; Hs99999903), Superoxide dismutase 1 (SOD1; Hs00533490_m1), Superoxide dismutase 2 (SOD2; Hs00167309_m1), Copper Chaperone for SOD (CCS; Hs00 192851_m1), Glutathione reductase (GSR; Hs00167317_ m1), Glutathione synthase (GSS; Hs00609286_m1), Peroxiredoxins (PRDXs; Hs00602020_mH), Glutaredoxin2 (GR X2; Hs00375015_m1), Catalase (CAT; Hs00156308_m1), Polynucleotide kinase/phosphatase (PNKP; Hs00892544_ $\mathrm{m} 1$ ). The results were normalized with the levels of the Glyceraldehyde 3-phosphate dehydrogenase (GAPDH; Hs 02758991_g1) housekeeping gene.

\section{Statistical analysis}

Three experiments in duplicate where performed for each analysis. The data are expressed as mean \pm S.D. and $t$ test was used for statistical analysis.

\section{Abbreviations}

CAT: catalase; CCS: copper chaperone for SOD; CHO: cholesterol; GRX: glutaredoxins; GSH: glutathione; GSR: GSH reductase; GSS: glutathione synthase; LMs: lipid microdomains; NLMs: nuclear lipid microdomains;
PNKP: polynucleotide kinase/phosphatase; PRDXs: peroxiredoxins; SODs: superoxide dismutases; SM: sphingomyelin..

\section{Competing interests}

The authors declare no competing interest.

\section{Authors' contributions}

MC and SC designed and performed the experiments; FSAI and FC contributed reagents/materials/ analysis tools and revised the manuscript; $A L, A F, R L, A T, M R C$ performed the experiments and analyzed the data; $T B$ analyzed the data and prepared figures; EA was the major investigator, she conceived and designed the experiments and wrote the paper. All authors read and approved the final manuscript.

\section{Authors' information}

Michela Codini researcher at the University of Perugia. Samuela Cataldi doctor in Medical Biotechnology, University of Perugia, Italy. Andrea Lazzarini PhD, CRABiON, Perugia, Italy. Anna Tagesian PhD, University of Perugia, Italy. Maria Rachele Ceccarini student PhD, University of Perugia, Italy. Alessandro Floridi, doctor in Chemistry, CRABiON, Perugia, Italy. Remo Lazzarini,

technician, CRABiON, Perugia, Italy. Francesco Saverio Ambesi-Impiombato MD, Professor University of Udine, Italy. Francesco Curcio, MD, Professor University of Udine, Italy. Tommaso Beccari, Professor University of Perugia, Italy. Elisabetta Albi, MD, PhD, visiting researcher at University of Perugia, Italy.

\section{Acknowledgements}

This study was supported by University of Udine and "Fondazione Cassa di Risparmio di Città di Castello", Italy.

\section{Author details}

${ }^{1}$ Department of Pharmaceutical Sciences, University of Perugia, Perugia, Italy. ${ }^{2}$ Laboratory of Nuclear Lipid BioPathology, CRABiON, Perugia, Italy.

${ }^{3}$ Department of Clinical and Biological Sciences, University of Udine, Udine, Italy.

Received: 8 November 2015 Accepted: 24 December 2015

Published online: 12 January 2016

\section{References}

1. Moon H, Ruelcke JE, Choi E, Sharpe LJ, Nassar ZD, Bielefeldt-Ohmann H, et al. Diet-induced hypercholesterolemia promotes androgen-independent prostate cancer metastasis via IQGAP1 and caveolin-1. Oncotarget. 2015;6:7438-53.

2. Hu J, La Vecchia C, Negri E, de Groh M, Morrison H, Mery L. Macronutrient intake and stomach cancer. Cancer Causes Control. 2015:26:839-47.

3. Pelton K, Coticchia CM, Curatolo AS, Schaffner CP, Zurakowski D, Solomon $\mathrm{KR}$, et al. Hypercholesterolemia induces angiogenesis and accelerates growth of breast tumors in vivo. Am J Pathol. 2014;184:2099-110.

4. Llaverias G, Danilo C, Mercier I, Daumer K, Capozza F, Williams TM, et al. Role of Cholesterol in the Development and Progression of Breast Cancer. Am J Pathol. 2011;178:402-13.

5. Iso H, Ikeda A, Inoue M, Sato S, Tsugane S. Serum cholesterol levels in relation to the incidence of cancer: the JPHC study cohorts. Int J Cancer. 2009;125:2679-86.

6. Pugliese L, Bernardini I, Pacifico N, Peverini M, Damaskopoulou E, Cataldi S, et al. Severe hypocholesterolaemia is often neglected in haematological malignancies. Eur J Cancer. 2010;46:1735-43.

7. Shankar J, Boscher C, Nabi IR. Caveolin-1, galectin-3 and lipid raft domains in cancer cell signalling. Essays Biochem. 2015;57:189-201.

8. Mollinedo F, Gajate C. Lipid rafts as major platforms for signaling regulation in cancer. Adv Biol Regul. 2015;57:130-46.

9. Di Vizio D, Solomon KR, Freeman MR. Cholesterol and cholesterol-rich membranes in prostate cancer: an update. Tumori. 2008;94:633-9.

10. Zhuang L, Kim J, Adam RM, Solomon KR, Freeman MR. Cholesterol targeting alters lipid raft composition and cell survival in prostate. cancer cells and xenografts. J Clin Invest. 2005;115:959-68.

11. Lin CJ, Lai CK, Kao MC, Wu LT, Lo UG, Lin LC, et al. Impact of cholesterol on disease progression. Biomedicine. 2015;5:7.

12. Cascianelli G, Villani M, Tosti M, Marini F, Bartoccini E, Magni MV, et al. Lipid microdomains in cell nucleus. Mol Biol Cell. 2008;19:5289-95.

13. Albi E, Villani M. Nuclear lipid microdomains regulate cell function. Commun Integr Biol. 2009;2:23-4. 
14. Lazzarini A, Macchiarulo A, Floridi A, Coletti A, Cataldi S, Codini M, et al. Very long chain fatty acid sphingomyelin in nuclear lipid microdomains of hepatocytes and hepatoma cells: can the exchange from c24:0 to c16:0 affect signal proteins and vitamin d receptor? Mol Biol Cell. 2015;26(13): 2418-25. doi:10.1091/mbc.E15-02-0071.

15. Cataldi S, Codini M, Cascianelli G, Tringali S, Tringali AR, Lazzarini A, et al. Nuclear lipid microdomain as resting place of dexamethasone to impair cell proliferation. Int J Mol Sci. 2014;15:19832-46.

16. Thomas D, Pollard TD, Cooper JA. Actin, a Central Player in Cell Shape and Movement. Science. 2009;326:1208-12.

17. Lambrechts A, Van Troys M, Ampe C. The actin cytoskeleton in normal and pathological cell motility. Int J Biochem Cell Biol. 2004;36:1890-909.

18. Lohr JG, Stojanov P, Lawrence MS, Auclair D, Chapuy B, Sougnez C, et al. Discovery and prioritization of somatic mutations in diffuse large B-cell lymphoma (DLBCL) by whole-exome sequencing. Proc Natl Acad Sci. 2012; 109:3879-84.

19. Bułdak RJ, Bułdak Ł, Kukla M, Gabriel A, Zwirska-Korczala K. Pol: Significance of selected antioxidant enzymes in cancer cell progression. J Pathol. 2014;65:167-75

20. Diehl C, Lipozencić J, Ledić-Drvar D. The basis of topical superoxide dismutase antipruritic activity. Acta Dermatovenerol Croat. 2009:17:25-39.

21. Lin C, Zeng H, Lu J, Xie Z, Sun W, Luo C, et al. Acetylation at lysine 71 inactivates superoxide dismutase 1 and sensitizes cancer cells to genotoxic agents. Oncotarget. 2015;6(24):20578-91.

22. Rhee SG, Chae HZ, Kim K. Peroxiredoxins: a historical overview and speculative preview of novel mechanisms and emerging concepts in cell signaling. Free Radic Biol Med. 2005;38:1543-52.

23. Sadhu SS, Callegari E, Zhao Y, Guan X, Seefeldt T. Evaluation of a dithiocarbamate derivative as an inhibitor of human glutaredoxin-1. J Enzyme Inhib Med Chem. 2013;28:456-62.

24. Jilani A, Ramotar D, Slack C, Ong C, Yang XM, Scherer SW, et al. Molecular cloning of the human gene, PNKP, encoding a polynucleotide kinase 3'phosphatase and evidence for its role in repair of DNA strand breaks caused by oxidative damage. J Biol Chem. 1999:274:24176-86.

25. Codini M, Cataldi S, Ambesi-Impiombato FS, Lazzarini A, Floridi A, Lazzarini $R$, et al. Gentamicin arrests cancer cell growth: the intriguing involvement of nuclear sphingomyelin metabolism. Int J Mol Sci. 2015;16:2307-019.

26. Bartoccini E, Marini F, Damaskopoulou E, Lazzarini R, Cataldi S, Cascianelli $G$, et al. Nuclear lipid microdomains regulate nuclear vitamin D3 uptake and influence embryonic hippocampal cell differentiation. Mol Biol Cell. 2011;22:3022-31.

27. Chai J, Wang S, Han D, Dong W, Xie C, Guo H. MicroRNA-455 inhibits proliferation and invasion of colorectal cancer by targeting RAF proto-oncogene serine/threonine-protein kinase. Tumour Biol. 2015;36:1313-13121.

28. Zhang L, Kim S, Ding W, Tong Y, Zhang X, Pan M, et al. Arsenic sulfide inhibits cell migration and invasion of gastric cancer in vitro and in vivo. Drug Des Devel Ther. 2015;9:5579-90.

29. Kang D, Lee KM, Park SK, Berndt SI, Peters U, Reding D, et al. Functional variant of manganese superoxide dismutase (SOD2 V16A) polymorphism is associated with prostate cancer risk in the prostate, lung, colorectal, and ovarian cancer study. Cancer Epidemiol Biomarkers Prev. 2007;16:1581-6.

30. Fiaschi Al, Cozzolino A, Ruggiero G, Giorgi G. Glutathione, ascorbic acid and antioxidant enzymes in the tumor tissue and blood of patients with oral squamous cell carcinoma. Eur Rev Med Pharmacol Sci. 2005:9:361-7.

31. Kim AD, Zhang $R$, Han X, Kang KA, Piao MJ, Maeng $Y H$, et al. Involvement of glutathione and glutathione metabolizing enzymes in human colorectal cancer cell lines and tissues. Mol Med Rep. 2015. doi:10.3892/mmr.2015.3902.

32. Ren $P$, Ye H, Dai L, Liu M, Liu X, Chai Y, et al. Peroxiredoxin 1 is a tumorassociated antigen in esophageal squamous cell carcinoma. Oncol Rep. 2013:30:2297-303.

33. Gong F, Hou G, Liu H, Zhang M. Peroxiredoxin 1 promotes tumorigenesis through regulating the activity of mTOR/p70S6K pathway in esophageal squamous cell carcinoma. Med Oncol. 2015;32:455

34. Demasi AP, Martinez EF, Napimoga MH, Freitas LL, Vassallo J, Duarte AS, et al. Expression of peroxiredoxins I and IV in multiple myeloma: association with immunoglobulin accumulation. Virchows Arch. 2013;463:47-55.

35. Sun QK, Zhu JY, Wang W, LV Y, Zhou HC, Yu JH, et al. Diagnostic and prognostic significance of peroxiredoxin 1 expression in human hepatocellular carcinoma. Med Oncol. 2014;31:786.
36. Hwang KE, Park C, Seol CH, Hwang YR, Hwang JS, Jung JW, et al. Elevated prx1 provides resistance to docetaxel, but is not associated with predictive significance in lung cancer. Tuberc Respir Dis. 2013;75:59-66.

37. Poschmann G, Grzendowski M, Stefanski A, Bruns E, Meyer HE, Stühler K. Redox proteomics reveal stress responsive proteins linking peroxiredoxin-1 status in glioma to chemosensitivity and oxidative stress. Biochim Biophys Acta. 1854;2015:624-31.

38. Tsao SM, Yin MC, Liu WH. Oxidant stress and B vitamins status in patients with non-small cell lung cancer. Nutr Cancer. 2007:59:8-13.

39. Esme H, Cemek M, Sezer M, Saglam H, Demir A, Melek H, et al. High levels of oxidative stress in patients with advanced lung cancer. Respirology. 2008;13:112-6.

40. Freschauf GK, Karimi-Busheri F, Ulaczyk-Lesanko A, Mereniuk TR, Ahrens A Koshy JM, et al. Identification of a small molecule inhibitor of the human DNA repair enzyme polynucleotide kinase/phosphatase. Cancer Res. 2009;69:7739-46.

41. Sens P, Plastino J. Membrane tension and cytoskeleton organization in cell motility. J Phys Condens Matter. 2015;27:273103.

42. Huang FK, Han S, Xing B, Huang J, Liu B, Bordeleau F, et al. Targeted inhibition of fascin function blocks tumour invasion and metastatic colonization. Nat Commun. 2015;6:7465.

43. Albi E, La Porta CA, Cataldi S, Magni MV. Nuclear sphingomyelin-synthase and protein kinase $C$ delta in melanoma cells. Arch Biochem Biophys. 2005:438:156-61.

44. Albi E, Lazzarini A, Lazzarini R, Floridi A, Damaskopoulou E, Curcio F, et al. Nuclear lipid microdomain as place of interaction between sphingomyelin and DNA during liver regeneration. Int J Mol Sci. 2013;14:6529-41.

45. Damaskopoulou E, Keri G, Jacob V, Lazzarini R, Cataldi S, Orfi L, et al. Protein kinase C $\zeta$ drives Sphingomyelin Metabolism in the Nucleus during Cell Proliferation. Curr Chem Biol. 2013;7:131-8.

46. Rossi G, Magni MV, Albi E. Sphingomyelin-cholesterol and double stranded RNA relationship in the intranuclear complex. Arch Biochem Biophys. 2007:459:27-32.

47. Albi E, Cataldi S, Bartoccini E, Magni MV, Marini F, Mazzoni F, et al. Nuclear sphingomyelin pathway in serum deprivation-induced apoptosis of embryonic hippocampal cells. J Cell Physiol. 2006;206:189-95.

\section{Submit your next manuscript to BioMed Central and we will help you at every step:}

- We accept pre-submission inquiries

- Our selector tool helps you to find the most relevant journal

- We provide round the clock customer support

- Convenient online submission

- Thorough peer review

- Inclusion in PubMed and all major indexing services

- Maximum visibility for your research

Submit your manuscript at www.biomedcentral.com/submit
) Biomed Central 